\title{
О ДРИМ-ГЕНОТИПИРОВАНИИ ВОЗБУДИТЕЛЕЙ БАКТЕРИОЗОВ КАРТОФЕЛЯ, ИХ АНТАГОНИСТОВ И БАКТЕРИЙ-ДЕСТРУКТОРОВ ДЛЯ РЕШЕНИЯ ЗАДАЧ ЗАЩИТЫ РАСТЕНИЙ И ЭКОЛОГИИ *
}

\author{
В.П. ТЕРЛЕЦКИЙ $1,2 \bowtie$, А.М. ЛАЗАРЕВ 1 , И.И. НОВИКОВА ${ }^{1}$, И.В. БОЙКОВА 1 , \\ В.Н. ЗЕЙРУК 3
}

Сохранение окружающей среды при интенсификации сельскохозяйственного и промышленного производства связывают с развитием экотехнологий, в том числе с биоконтролем патогенов растений и биоремедиацией. Микроорганизмы - продуценты биопрепаратов и деструкторы углеводородов характеризуются высокой спонтанной вариабельностью, что может приводить к изменению их активности, поэтому при стабилизирующем отборе необходимо периодически подтверждать их штаммовую принадлежность. Молекулярно-генетические методы исследований дают возможность идентифицировать возбудителей заболеваний с полной характеристикой их наследственного материала. В этой работе представлены данные о применении разработанного нами метода двойного расщепления и избирательного мечения (ДРИМ) для изучения генетических профилей бактерий-фитопатогенов родов Pseudomonas, Pectobacterium и их антагонистов Bacillus subtilis (Bs), подтверждена высокая биологическая эффективность двух отселектированных штаммов $B s$ (M-22 и И5-12/23) против бактериальных болезней картофеля при хранении клубней в производственных условиях. Также впервые выполнена генетическая идентификация (паспортизация) штаммов бактерий-деструкторов рода Pseudomonas, пригодных для решения природоохранных задач. Цель исследований заключалась в оценке генетического разнообразия бактерий нескольких родов для отбора наиболее эффективных штаммов-антагонистов и штаммов-деструкторов. Примененный нами метод генотипирования основан на использовании двух эндонуклеаз рестрикции для расщепления геномной ДНК бактерии. Присутствующая в реакционной смеси ДНК-полимераза (Таq) обеспечивает мечение фрагментов ДНК биотинилированным дезоксицитозинтрифосфатом (ВіоdCTP). Метка включается только в ДНК, имеющую 3'-усеченные концы, которые образует первый ферментом. Вторая эндонуклеаза рестрикции дает только тупые концы фрагментов, которые не способны присоединять метку. В результате переноса на фильтр визуализируются 20-50 четко различимых фрагментов ДНК, число и распределение которых характерно для каждого бактериального штамма. Генотипирование двух близкородственных штаммов Pectobacterium atrosepticum позволяет распознать около 50 фрагментов ДНК, более 20 \% которых специфичны для одного из сравниваемых штаммов. Мы использовали две пары эндонуклеаз рестрикции - XbaI/DraI и $\mathrm{XbaI/Eco24I;} \mathrm{полученные} \mathrm{результаты} \mathrm{указывают} \mathrm{на} \mathrm{одинаковую} \mathrm{дискриминационную} \mathrm{способность}$ ферментов при сопоставлении штаммов $P$. atrosepticum Д822 и $\Gamma 784$ по генетическим профилям. При генотипировании бактерий рода Pseudomonas оптимальной была пара BcuI/Eco32I, для Bs первая рестриктаза - SgsI (39 сайтов расщепления), вторая (уменышает размер получаемых фрагментов ДНК) - Есо32I. Методом ДРИМ получены генетические профили микроорганизмов родов Pectobacterium и Pseudomonas, характеризующие индивидуальность каждого штамма. Отмечены существенные генетические различия между видами Ps. fluorescens и Ps. marginalis. При этом выявлены идентичные фрагменты ДНК, что указывает на родовую филогенетическую близость этих видов. При искусственном заражении клубней установлена высокая антагонистическая активность Bs И5-12/23 в отношении штаммов $P$. atrosepticum и $P$. carotovorum subsp. catovorum. Подтверждена высокая биологическая эффективность двух отселектированных штаммов Bs (М-22 и И512/23) против бактериальных болезней картофеля при хранении клубней. Штамм Bs И5-12/23 обладал более выраженной антагонистической активностью против возбудителей мягкой бактериальной и кольцевой гнилей, а также фузариоза. При хранении обработка штаммами-антагонистами снижала пораженность почти вдвое по сравнению с контролем (30,4-35,5 \% здоровых клубней против $13,3 \%)$. По результатам генотипирования биодеструкторов рода Pseudomonas сформирована коллекция штаммов, утилизирующих трудноокисляемые соединения, включая тяжелые фракции нефти и полиароматические углеводороды (бензопирен, хризен, фенантрен, антрацен, хризен, нафталин), что позволяет составлять ассоциации штаммов-деструкторов для утилизации конкретных загрязнителей. Таким образом, ДРИМ-генотипирование позволяет идентифицировать бактериальные штаммы для подтверждения их происхождения при разработке и применении биопрепаратов различного назначения.

\footnotetext{
* Работа выполнена в соответствии с Государственным заданием на оказание государственных услуг по Разделу 5. «Защита и биотехнология растений» Программы ФНИ государственных академий наук на 2013 2020 гг., тема 15 «Молекулярно-биологические и нанотехнологические основы разработки биологических и химических средств защиты растений нового поколения в целях эффективного и безопасного их использования в интегрированных системах защиты».
} 
Ключевые слова: эндонуклеазы рестрикции, генотипирование, фитопатогены, микробыантагонисты, биодеструкторы, Pectobacterium, Pseudomonas, Bacillus subtilis, Solanum tuberosum L., картофель.

Сохранение окружающей среды при интенсификации сельскохозяйственного и промышленного производства - один из глобальных современных вызовов. Решение этой задачи связывают с экотехнологиями, в том числе с биоконтролем патогенов растений и биоремедиацией.

Существенные потери урожая от бактериозов составляют серьезную проблему для картофелеводства в Российской Федерации. Наиболее распространенным заболеванием считается черная ножка, или мягкая гниль. Его основной возбудитель - микроорганизмы из рода Pectobacterium (син. Erwinia) (1-3). Полупаразитные бактерии рода Pseudomonas (Ps. fluorescens и Ps. marginalis), продуцирующие пектолитические ферменты, также активно участвуют в процессе поражения и последующего разложения клубней, особенно в период зимнего хранения растительной продукции.

Методы фитосанитарного мониторинга на популяционном уровне позволяют идентифицировать как штаммы возбудителей болезней, обусловливающих интенсивность инфекционного процесса в экосистеме, так и интродуцированные для его контроля микроорганизмы-супрессоры $(4,5)$. Генотипирование микроорганизмов применяют при изучении генетических профилей бактериальных штаммов для их идентификации и индивидуализации $(3,6,7-9)$. По результатам генотипирования каждому штамму можно присвоить «штрих-код», что крайне важно для определения видов бактерий и их антагонистов (6). После интродукции микроорганизма-антагониста в ризо- или филлосферу растения его присутствие в микробном сообществе подтверждают посредством молекулярно-генетических методов, определяют степень и длительность доминирования, которые обеспечат эффективное подавление плотности популяций фитопатогенных видов и динамическую устойчивость почвенных микробиоценозов. Для углубленной идентификации возбудителей важно проводить генотипирование при фитосанитарном контроле болезней картофеля, вызываемых бактериями Pectobacterium и Dickeya (10-12).

Как показали исследования, генотипирование позволяет быстро и с высокой точностью идентифицировать коллекционные штаммы рода Bacillus, близкие по морфолого-культуральным особенностям, но различающиеся по составу комплексов продуктов метаболизма. С его помощью можно распознать отдельные штаммы и группы близкородственных штаммов $B s$ и выявить интродуцированные микроорганизмы-супрессоры, что дает основания рекомендовать генотипирование как для контроля происхождения штаммов, так и для фитосанитарного мониторинга (13-15).

В настоящее время антагонисты возбудителей болезней и биопрепараты на их основе с успехом применяют для регуляции плотности популяций фитопатогенных видов в агробиоценозах (16-18). Высокая биологическая активность биопрепаратов показана на многих сельскохозяйственных культурах (19-22). Подбор биопрепаратов на основе данных фитосанитарного мониторинга с учетом биологических особенностей и спектра действия штаммов-продуцентов в значительной степени определяет эффективность микробиологической и интегрированной защиты картофеля от болезней $(23,24)$. Представляют интерес способы блокирования химических сигналов коммуникации (QS, quorum sensing) в популяциях патогенов за счет выделения определенных ингибиторов бактериями-антагонистами $(25,26)$.

Наиболее эффективные и широко используемые (около 90-95\% рынка биопестицидов) средства борьбы с болезнями - препараты на основе 
грамположительных спорообразующих бактерий семейства Bacilliaceae, способных синтезировать биологически активные соединения различной химической природы (27-29).

Существенное значение имеет плотность популяций микроорганизмов-супрессоров и антагонистов возбудителей заболеваний растений, интродуцированных в почвенный микробиоценоз (30-33). В этой связи для прогнозирования интенсивности развития болезни, оценки эффективности биологического контроля популяций фитопатогенных видов и корректировки регламентов применения биопрепаратов необходимо выявлять и идентифицировать интродуцированные штаммы микроорганизмов-супрессоров.

Еще одна важная область применения генетической паспортизации микроорганизмов связана с загрязнением окружающей среды углеводородами (утечка при нефтедобыче, разливы нефтепродуктов после аварий на трубопроводах и нефтеперерабатывающих заводах). Обозначенная проблема в последние годы обостряется, при этом все активнее применяются деструкторы углеводородов бактериальной природы, которые используют углерод таких продуктов в своем метаболизме. Отбор и генетическая паспортизация наиболее активных штаммов-деструкторов дает возможность эффективнее решать подобные экологические задачи.

На основе ранее предложенной нами идеи двойного расщепления и избирательного мечения (ДРИМ) (7) был разработан метод генетической идентификации и паспортизации штаммов Bacillus subtilis (Bs) и некоторых представителей рода Streptomyces - перспективных антагонистов фитопатогенов (6). Метод ранее был апробирован на штаммах, различающихся по физиолого-биохимическим признакам и составу вторичных метаболитов, которые определяют антибиотическую активность. Также доказана его высокая разрешающая способность.

В этой работе представлены данные о применении метода ДРИМ для изучения генетических профилей бактерий-фитопатогенов родов Pseudomonas, Pectobacterium и их антагонистов (Bacillus subtilis). Полученные peзультаты могут использоваться при разработке биопрепаратов против фитопатогенов на основе их антагонистов и для контроля происхождения штаммов. Подтверждена высокая биологическая эффективность двух отселектированных штаммов $B s$ (М-22 и И5-12/23) против бактериальных болезней картофеля при хранении клубней в производственных условиях. Также впервые выполнена идентификация (паспортизация) штаммов бактерий-деструкторов (род Pseudomonas), пригодных для решения природоохранных задач.

Цель исследований - оценить генетическое разнообразие бактерий родов Bacillus, Pectobacterium и Pseudomonas для отбора наиболее эффективных штаммов-антагонистов и штаммов-деструкторов.

Методика. Штаммы фитопатогенных бактерий, использованные в работе, были паспортизированы и входят в состав Государственной коллекции фитопатогенных микроорганизмов и их вредителей ФГБНУ Всероссийского НИИ защиты растений (зарегистрирована в WFCC WDCM 760, Япония, 28.01.1998). Штаммы P. atrosepticum Д822 и Г784 выделены из пораженных клубней картофеля на территории Ленинградской области. Паспортизированные штаммы P. atrosepticum 1944 и P. carotovorum subsp. catovorum 481 получены из Государственной коллекции фитопатогенных микроорганизмов и сортов растений-идентификаторов (дифференциаторов) патогенных штаммов микроорганизмов ФГБНУ Всероссийского НИИ фитопатологии. Паспортизированный штамм Ps. fluorescens 894 получен из Всероссийской коллекции микроорганизмов ИБФМ Института биохимии и физиологии микроорганизмов им. Г.К. Скрябина РАН. Штамм Ps. mar- 
ginalis (ранее относился к группе Ps. xanthochlora) входит в состав коллекции фитопатогенных микроорганизмов ФГБНУ Всероссийского НИИ картофельного хозяйства им. А.Г. Лорха.

Бактерии выделяли общепринятыми в фитобактериологии методами (34) из растений картофеля с симптомами бактериальных гнилей. Бактерии идентифицировали с помощью классических физиолого-биохимических и молекулярных методов (polymerase chain reaction, PCR) (34). Для рода Pseudomonas первичный анализ проводили по системе LOPAT (леван, оксидаза, разжижение картофеля, аргининдигидролаза, реакция сверхчувствительности), а также по флуоресцирующему пигменту на среде Кинга Б, для рода Pectobacterium (патотипы carotovora и atroseptica) - по разжижению пектата и мацерации тканей картофеля.

Генотипирование бактерий родов Pectobacterium и Pseudomonas ocyществляли методом двойного расщепления и избирательного мечения (ДРИМ) $(7,8)$. При предварительной отработке методики на двух штаммах Pectobacterium и двух - Pseudomonas был проведен поиск in silico (http://insilico.ehu.eus/), который показал, что лучший первый фермент рестрикции для микроорганизмов рода Pseudomonas - BcuI (A $\downarrow$ CTAGT, 78 сайтов расщепления в референтном геноме $P$. fluorescens Pf-5, «Thermo Fisher Scientific, Inc.», США), а для представителей рода Pectobacterium - XbaI (T $\downarrow$ CTAGA, 87 сайтов расщепления в референтном геноме $P$. carotovorum subsp. catovorum, «Thermo Fisher Scientific, Inc.», США). Для первого фермента характерно меньшее число сайтов расщепления в ДНК с 3'-усеченными концами, способными к связыванию меченого Віо-dCТР. Второй фермент, расщепляющий ДНК в большем числе сайтов, образует тупые концы, к которым не может присоединиться эта метка.

Таким образом, в реакционной смеси после ферментативного расщепления присутствует ограниченное число меченых фрагментов ДНК, которые могут быть разделены и распознаны визуально. В отношении бактерий рода Pseudomonas лучшим вторым ферментом следует считать Есо32I (GAT $\downarrow$ ATC, 1556 сайтов расщепления в референтном геноме, «Thermo Fisher Scientific, Inc.», США), для микроорганизмов рода Pectobacterium DraI (TTT $\downarrow$ AAA, 1332 сайта расщепления, «Thermo Fisher Scientific, Inc.», США). Пары ферментов совместимы в одном реакционном буфере. В качестве второго фермента для штаммов рода Pectobacterium проанализированы также Msp20I (TGG $\downarrow$ CCA, 1028 сайтов расщепления, «Thermo Fischer Scientific, Inc.», США) и Eco24I (GRGCY」C, 1314 сайтов расщепления, «Thermo Fischer Scientific, Inc.», США) (6).

Анализ штаммов $B s$ провели с помощью пары ферментов SgsI и Eco32I. В геноме B. subtilis имеется 39 сайтов расщепления (GG $\downarrow$ CGCGCC) для первого фермента, при этом образуются липкие концы, которые способны присоединять Bio-dCTP с помощью Таq-полимеразы. Эта пара ферментов совместима в буфере R («Thermo Fischer Scientific, Inc.», США).

ДРИМ-реакция сводилась к внесению в пробирку типа Эппендороф 15 мкл дистиллированной воды, 2 мкл бактериальной ДНК, 2 мкл соответствующего буфера, подходящего для обеих эндонуклеаз рестрикции, и 1 мкл предварительно подготовленной смеси, включающей эндонуклеазы рестрикции, метку Bio-dCTР и ДНК-полимеразу, например Таq-полимеразу $(6,12)$.

Реакцию проводили в твердотельном термостате Термит (ООО «ДНК-технологии», Россия) при $37{ }^{\circ} \mathrm{C}$ в течение 1-2 ч. Для проведения электрофореза использовали Tris-ацетатный буфер и 0,8 \% агарозный гель, напряжение составляло 1,5 В/см. Вакуумный перенос фрагментов ДНК на нейлоновый фильтр осуществляли сразу же после электрофореза в приборе 
VacuGene XL Vacuum Blotting System ${ }^{\mathrm{TM}}$ («GE Healthcare», США). При этом перевод ДНК из двухцепочечного состояния в одноцепочечное не требовался, поскольку отсутствовала стадия молекулярной гибридизации. Детекция фрагментов ДНК на фильтре была основана на выявлении ферментативной активности щелочной фосфатазы в присутствии субстратов 5-бромо4-хлоро-3-индолилфосфата и хлористого нитросинего тетразолия (NBT, «Thermo Fischer Scientific, Inc.», США). Несвязанную метку отмывали в буфере с малеиновой кислотой и солью.

Штаммы Bs M-22 и 5-И-12/23, использованные в работе, ранее были отобраны по признаку высокой антагонистической активности и депонированы в Государственной коллекции фитопатогенных микроорганизмов и их вредителей ФГБНУ ВИЗР. Бактерии выращивали на питательной среде (30 г/л кукурузного экстракта, 15 г/л мелассы; $\mathrm{pH}$ 7,2) на лабораторной качалке Biosan OS-20 («Диаэм», Россия) при 220 об/мин и 28 C (колбы объемом 750 мл с 100 мл среды) в течение 72 ч. Отбор проб и оценку развития культуры осуществляли с помощью светового микроскопа Axio Imager A-2 («Karl Zeiss», Германия) один раз в сутки. Титр жизнеспособных клеток определяли методом серийных разведений культуральной жидкости с последующим высевом на среду СПА и подсчетом числа выросших колоний.

Для оценки биологической активности штамма Bs 5-И-12/23 при искусственном заражении отбирали по 10 неповрежденных, визуально здоровых клубней картофеля (Solanum tuberosum L.) сорта Сантэ в 5-кратной повторности для каждого варианта. На их поверхность скальпелем наносили механические повреждения глубиной 10 мм, в которые капиллярным шприцом вводили 0,3 мл смеси бактериальных суспензий 1-суточных культур $P$. atrosepticum 1944 и $P$. carotovorum subsp. catovorum 481 с титрами $10^{6} \mathrm{KOE/мл} \mathrm{в} \mathrm{стерильной} \mathrm{дистиллированной} \mathrm{воде.} \mathrm{Затем} \mathrm{клубни} \mathrm{об-}$ рабатывали культуральной жидкостью штамма $B s 5-И-12 / 23$ с титром $10^{8}$ и $10^{9} \mathrm{KOE/мл.} \mathrm{В} \mathrm{контроле} \mathrm{клубни} \mathrm{обрабатывали} \mathrm{водой,} \mathrm{в} \mathrm{стандарте} \mathrm{-} \mathrm{кон-}$ тактным фунгицидным протравителем Максим, КС (0,2 л/т) («Syngenta AG», Швейцария). Зараженность бактериозами оценивали на 8-10-е сут. Индекс поражения рассчитывали по формуле:

$$
x=\frac{d h}{100},
$$

где $\mathrm{d}$ - диаметр зоны загнивания (поражения), мм, h - глубина зоны загнивания, мм.

Биологическую активность штаммов $B s$ 5-И-12/23 и М-22 при хранении урожая в насыпи клубней картофеля изучали в зимний период 20182019 годов в картофелехранилище ФГБНУ ФИЦ картофеля им. А.Г. Лорха (Московская обл., п. Красково) с учетом динамики развития заболеваний. Для оценки антагонистической активности штамма проводили предварительный фитопатологический анализ клубней картофеля (ГОСТ 33966-2016 «Картофель семенной. Технические условия и методы определения качества». М., 2020) (35). Чтобы оценить биологическую активность штамма в провокационных условиях, способствующих развитию гнилей, отбирали клубни из партии картофеля сорта Удача. Перед закладкой на хранение клубни обрабатывали культуральной жидкостью штамма $B S 5-И-12 / 23$ с титром $10^{8}$ и $10^{9} \mathrm{KOE/мл.} \mathrm{В} \mathrm{контроле} \mathrm{клубни} \mathrm{обрабатывали} \mathrm{водой,} \mathrm{в} \mathrm{стандар-}$ тах - культуральной жидкостью штамма $B s$ M-22 с титром $10^{9} \mathrm{KOE} /$ мл и контактным фунгицидным протравителем Максим, КС (0,2 л/т) («Syngenta AG», Швейцария), рекомендованным для обработки семенного картофеля перед закладкой на хранение для защиты от гнили разной этиологии, в том числе мокрой гнили. Масса образца клубней составляла 5 кг, расход рабо- 
чего раствора -3 л/т, повторность опыта 10-кратная. После подсушивания обработанный материал в сетках размещали в картофелехранилище в насыпи картофеля на глубине 20-30 см от поверхности в условия повышенной влажности и температуры с целью провокации имеющейся в клубнях инфекции и выявления эффективности изучаемого штамма. Клубневые инфекции учитывали через 6 мес хранения. Оценивали распространенность парши обыкновенной, кольцевой гнили, фитофтороза и фузариоза по доле (\%) больных клубней. Биологическую эффективность рассчитывали по формуле:

$$
\text { БЭ }=\frac{\mathrm{a}-\text { б }}{\mathrm{a}} \cdot 100 \% \text {, }
$$

где БЭ - снижение распространенности или развития болезни к контролю, $\%$; а - распространенность или развитие болезни в контроле, \%, б - распространенность или развитие болезни в опытном варианте, \%.

Статистическую обработку данных проводили методами дисперсионного анализа с помощью пакета программ Statistica 6.0 («StatSoft, Inc.» США). Для статистической обработки использовали методы параметрической статистики. Рассчитывали средние значения $(M)$, стандартные ошибки средних $( \pm \mathrm{SEM})$ и их 95 \% доверительные интервалы по $t$-критерию Стьюдента.

Результаты. Генотипирование методом ДРИМ можно кратко описать как последовательное выполнение следующих этапов: 1 - расщепление геномной ДНК одновременно двумя эндонуклеазами рестрикции и мечение отдельных фрагментов ДНК (содержащих 3'-усеченные концы) остатком биотина; 2 - электрофоретическое разделение фрагментов ДНК по длине; 3 - вакуумный перенос ДНК в дистиллированной воде на фильтр; 4 - выявление фрагментов, меченых биотином, в цветной химической реакции (6).

Метод ДРИМ был успешно апробирован на Ps. aeruginosa, Staphylococcus aureus, Salmonella spp. и других возбудителях инфекционных заболеваний, представляющих интерес в медицинской и ветеринарной практике $(7,8)$. Использование теста ДРИМ также позволило выявить генетические профили у микроорганизмов родов Pectobacterium и Pseudomonas, характеризующие индивидуальность каждого из них (рис. 1) (12). Например, мы отмечали существенные различия между видами Ps. fluorescens и Ps. marginalis. Штаммы P. atrosepticum Д822 и Г784 сравнивали на основе двух комбинаций ферментов XbaI-DraI и XbaI-Eco24I в реакционном буфере Tango ${ }^{\text {тм }}$ («Thermo Fischer Scientific, Inc.», США). Указанные пары ферментов помогли нам детектировать у них около 50 фрагментов ДНК. Несмотря на определенные межвидовые различия у этих видов, генотипирование позволило обнаружить группу идентичных фрагментов ДНК, что указывает на родовую филогенетическую близость. Обе комбинации ферментов рестрикции выявили определенную дифференциацию между штаммами P. atrosepticum Д822 и Г784 по генетическим профилям.

Таким образом, геномный анализ методом ДРИМ количественно показывает как межвидовые различия, так и генетические вариации внутри вида на уровне отдельных штаммов (12). Например, сравнение микроорганизмов рода Pectobacterium выявило более 10 фрагментов ДНК, характерных для каждого из них. Анализ их генетических профилей позволяет сделать заключение о преимуществе использования пары XbaI-DraI, которая детектирует, наряду с короткими фрагментами, более длинные, достигающие 23000 п.н. и группирующиеся в верхней части фильтра (см. рис. 1). 

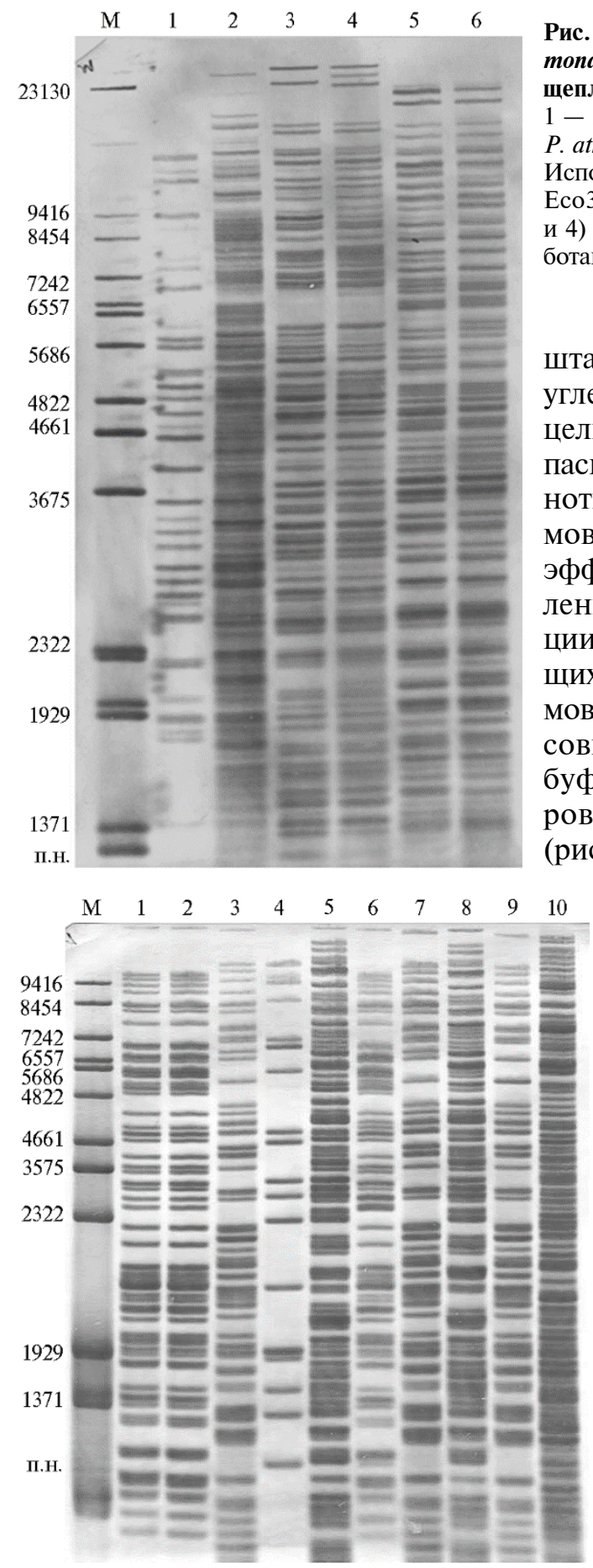

Рис. 1. Генотипирование штаммов родов Pseudomonas и Pectobacterium методом двойного pacщепления и избирательного мечения (ДРИМ): 1 - Ps. fluorescens 894, 2 - Ps. marginalis, 3 и 5 P. atrosepticum Д822, 4 и $6-$ P. atrosepticum $Г 784$. Используемые эндонуклеазы рестрикции: BcuIEco32I (дорожки 1 и 2), XbaI-DraI (дорожки 3 и 4) и XbaI-Eco24I (дорожки 5 и 6). M - разработанный маркер длин фрагментов ДНК (12).

Работу продолжили на группе штаммов бактерий - деструкторов углеводородов из рода Pseudomonas с целью их молекулярно-генетической паспортизации. Проведенное ранее генотипирование клинических штаммов Pseudomonas aeruginosa показало эффективность метода ДРИМ в выявлении путей распространения инфекции и идентификации циркулирующих у пациентов бактериальных штаммов (7). Пара ферментов BcuI-Eco32I, совместимых в одном реакционном буфере, позволяла четко визуализировать более 40 фрагментов ДНК (рис. 2).

Рис. 2. Генотипирование групाы бактерий деструкторов углеводородов из рода Pseudomonas методом двойного расщепления и избирательного мечения (ДРИМ) с использованием эндонуклеаз рестрикции BcuIEco32I: 1 - 1-1, 2 - 10-1, 3 - 14-2, $4-$ ку-1, 5 - ко-1, 6 - Рр-2, 7 - лб 3-2, 8 Pp-5, 9 - Pp-7, $10-$ P.Pol Г+. M - разработанный маркер длин фрагментов ДНК (12).

Выполненное нами изучение бактерий-деструкторов рода Pseudomonas, характеризующихся способностью усваивать углерод из техногенно загрязненных почвенных и водных экосистем в разных природно-климатических зонах, выявило значительное генетическое разнообразие штаммов. На их основе были созданы стабильные ассоциации, эффективно и быстро окисляющие раз-

личные токсиканты в короткий срок в разных экологических условиях. В состав сформированной коллекции биодеструкторов, хранящейся в ФГБНУ ВИЗР, входят штаммы, утилизирующие трудноокисляемые соединения, включая тяжелые фракции нефти и полиароматические углеводороды (в частности, бензопирен, хризен, фенантрен, антрацен, хризен, нафталин), что позволяет составлять бактериальные ассоциации для утилизации различных загрязнений. 
Разработанная нами методика генотипирования на основе ДРИМ была также успешно апробирована для идентификации 13 штаммов $B s$ (табл. 1) (6), обладающих высокой антагонистической активностью в отношении широкого круга фитопатогенных грибов и бактерий и входящих в состав Государственной коллекции микроорганизмов, патогенных для растений и их вредителей ФГБНУ ВИЗР $(6,8)$. В настоящее время коллекция включает более 8000 штаммов микроорганизмов, в том числе более 200 отселектированных штаммов с высокой полифункциональной активностью - перспективных продуцентов биопрепаратов разного целевого назначения (31).

1. Характеристика штаммов Bacillus subtilis, отобранных для генотипирования методом двойного расщепления и избирательного мечения (ДРИМ) (6)

\begin{tabular}{|c|c|c|}
\hline Штамм & Место выделения, источник & Биологическая активность \\
\hline B. subtilis B-10 & Ленинградская обл. (Россия), зоокомпост & Фунгицидная, фиторегуляторная \\
\hline B. subtilis $\mathrm{M}-22$ & Украина, воздушная среда & $\begin{array}{l}\text { Фунгицидная, бактерицидная, } \\
\text { фиторегуляторная }\end{array}$ \\
\hline B. subtilis $1-И$ & Индия, поверхность семян огурца & Фунгицидная \\
\hline B. subtilis $2-И$ & Индия, поверхность семян пшеницы & Фунгицидная \\
\hline B. subtilis 3-И & Индия, поверхность семян пшеницы & Фунгицидная \\
\hline B. subtilis 4-И & Индия, поверхность семян фасоли & Фунгицидная \\
\hline B. subtilis $5-И-12 / 23$ & Индия, поверхность семян томата & $\begin{array}{l}\text { Фунгицидная, бактерицидная, } \\
\text { фиторегуляторная }\end{array}$ \\
\hline B. subtilis $1-\mathrm{K}$ & Китай, ризосфера огурца & Фунгицидная \\
\hline B. subtilis ФР-318 & $\begin{array}{l}\text { Коллекция ФГБНУ Всероссийского НИИ } \\
\text { сельскохозяйственной микробиологии }\end{array}$ & Фосфатрастворяющая \\
\hline B. subtilis ФР-327 & То же & Фосфатрастворяющая \\
\hline B. subtilis var. niger $147 / 48 / 314$ & То же & Фунгицидная \\
\hline B. subtilis var. niger $110 / 723$ & То же & Фунгицидная \\
\hline B. subtilis var. niger $85 / 3 / 8$ & То же & Фунгицидная \\
\hline
\end{tabular}

С использованием метода ДРИМ мы выявили 7 групп генотипически идентичных кластеров и уникальных штаммов $B s:$ 1-я группа 147/48/314, 110/723, 85/3/8, 2-я - 1-И, 2-И, 3-И, 4-И, 5-И-12/23, 3-я ФР-318, 4-я - ФР-327, 5-я - 1-К, 6-я - В-10, 7-я - М-22. Отмеченное распределение по генотипам несколько отличается от полученных ранее данных, когда мы выявили всего шесть групп генотипов (6). В генотипировании, выполненном в настоящем исследовании, штамм М-22, который используется в коммерческих биопрепаратах для защиты растений, имел уникальный генотип, отличающийся от всех остальных. В предыдущей работе (6) этот микроорганизм попал в большой кластер генетически идентичных штаммов. Последующие эксперименты с повторным выращиванием подтвердили опасения, что произошла контаминация при культивировании штамма М-22 бактериями группы И. В остальном генотипы анализируемых бактерий совпали с описанными нами в предыдущей работе.

Обращает на себя внимание группа штаммов 1-И, 2-И, 3-И, 4-И, 5-И-12/23, которые генетически не отличались друг от друга, хотя были выделены из разных источников и имели некоторые различия в антагонистической активности. Объяснением этого может быть генетическая и эволюционная близость штаммов при одновременном наличии разных генов, определяющих биологические свойства. Другими словами, геномы могут быть близкими, но различаться по небольшому числу структурных генов. При появлении все большего числа изменений в геноме в процессе эволюции или селекции на определенные признаки появляются видимые различия в геномной ДНК. Сравнение фрагментов ДНК на фильтре мы проводили визуально. Существующие программы сравнения генетических профилей, например BioNumerics ${ }^{\mathrm{TM}}$ (https://www.applied-maths.com/down- 
load/software), целесообразно использовать при большом числе сравниваемых штаммов. Согласно инструкции к указанной программе, конечным этапом компьютерного сравнения становится визуальный контроль совпадения фрагментов. В нашем случае, учитывая небольшое число штаммов, предпочтение было отдано визуальной оценке. Различия в числе и распределении фрагментов ДНК дают основание утверждать, что образцы представляют собой генетически различные штаммы. В то же время, если ДНК в образцах не различается, есть вероятность, что они могут иметь разный генетический профиль при использовании иного метода генотипирования.

Наши исследования показали, что метод ДРИМ дает возможность идентифицировать как штаммы возбудителей бактериозов при развитии эпифитотии, так и интродуцированные в агроценоз микроорганизмы-антагонисты, что позволит в дальнейшем изучать особенности отношений паразит-хозяин в системе растение-фитопатоген-антагонист на популяционном уровне.

2. Биологическая эффективность штамма Bacillus subtilis И-5-12/23 (Bs) по отношению к возбудителям мягкой гнили Pectobacterium atrosepticum 1944 и P. carotovorum subsp. catovorum 481 на картофеле (Solanum tuberosum L.) сорта Сантэ при искусственном заражении $(N=5, n=10, M \pm \mathrm{SEM})$

\begin{tabular}{|c|c|c|c|}
\hline Вариант & $\begin{array}{l}\text { Распространенность } \\
\text { болезни, \% }\end{array}$ & $\begin{array}{l}\text { Индекс развития } \\
\text { болезни }\end{array}$ & $\begin{array}{l}\text { Биологическая } \\
\text { эффективность, \% }\end{array}$ \\
\hline Контроль (без обработки) & $80,7 \pm 4,3$ & $4,04 \pm 1,8$ & \\
\hline B. subtilis, $10^{9} \mathrm{KOE/мл}$ & 0 & 0 & 100 \\
\hline B. subtilis, $10^{8} \mathrm{KOE} / л$ & $20,4 \pm 2,8$ & $0,02 \pm 0,01$ & $99,5 \pm 0,3$ \\
\hline Максим, КС, 0,2 л/т (стандарт) & $80,1 \pm 6,6$ & $0,9 \pm 0,1$ & $77,7 \pm 0,2$ \\
\hline $\mathrm{HCP} 05$ & 9,8 & 0,1 & 0.5 \\
\hline
\end{tabular}

Изучение активности $B s$ в отношении возбудителей бактериальных и грибных болезней картофеля in vitro на широком спектре тест-культур показало, что для защиты от бактериозов наиболее перспективен штамм $B s$ И-5-12/23 (32). В наших опытах при искусственном заражении клубней P. atrosepticum 1944 и P. carotovorum subsp. catovorum 481 было отмечено существенное снижение пораженности картофеля при хранении после обработки инфицированного растительного материала $B s$ И-5-12/23 (табл. 2). Индекс развития мягкой бактериальной гнили составлял 0-0,2, в контроле $-4,04$. Биологическая эффективность химического фунгицида Максим, КС составила 77,7 \%, в вариантах с обработкой клубней суспензией штамма Bs И-5-12/23 - $100 \%$.

3. Биологическая эффективность штаммов Bacillus subtilis И-5-12/23 и М-22 против болезней картофеля сорта Удача при хранении ( $M \pm \mathrm{SEM}$, Московская обл., п. Красково, зимний период 2018-2019 годов)

\begin{tabular}{|c|c|c|c|c|c|c|}
\hline \multirow{3}{*}{ Вариант } & \multicolumn{6}{|c|}{ Доля клубней, \% } \\
\hline & \multirow[b]{2}{*}{ здоровых } & \multicolumn{5}{|c|}{ пораженных } \\
\hline & & всего & $\begin{array}{l}\text { парша обык- } \\
\text { новенная }\end{array}$ & \begin{tabular}{|l|} 
кольцевая \\
гниль
\end{tabular} & фитофтороз & фузариоз \\
\hline Контроль (вода) & $13,3 \pm 1,1$ & $86,7 \pm 2,5$ & $52,3 \pm 2,2$ & $7,4 \pm 0,3$ & $11,8 \pm 1,2$ & $15,2 \pm 1,5$ \\
\hline B. subtilis М-22, $10^{9}$ КОЕ/мЛ & $30,4 \pm 1,9$ & $69,6 \pm 3,3$ & $47,3 \pm 1,7$ & $4,8 \pm 0,2$ & $8,5 \pm 0,7$ & $9,0 \pm 0,8$ \\
\hline B. subtilis И-5-12/23, $10^{9}$ КОЕ/мЛ & $32,4 \pm 1,7$ & $67,6 \pm 1,2$ & $53,8 \pm 4,5$ & $2,6 \pm 0,1$ & $8,2 \pm 0,3$ & $3,0 \pm 0,1$ \\
\hline B. subtilis И-5-12/23, $10^{8}$ КОЕ/мЛ & $35,5 \pm 2,0$ & $64,5 \pm 2,6$ & $55,7 \pm 3,7$ & $2,9 \pm 0,2$ & $4,4 \pm 0,2$ & $1,5 \pm 0,1$ \\
\hline Максим, КС, 0,2 л/т & $30,0 \pm 1,5$ & $70,0 \pm 4,3$ & $54,1 \pm 3,3$ & $3,5 \pm 0,1$ & $8,3 \pm 0,4$ & $4,1 \pm 0,2$ \\
\hline HCP05 & 2,3 & 5,4 & 6,6 & 0,4 & 1,4 & 0,2 \\
\hline
\end{tabular}

Сравнение эффективности штаммов $B s$ И-5-12/23 и М-22 в условиях хранилища показало, что первый обладал более выраженной антагонистической активностью по отношению к кольцевой гнили, фитофторозу и фузариозу (табл. 3). В отношении парши обыкновенной существенных разли- 
чий в эффективности препаратов мы не отмечали.

Анализ полученных данных свидетельствует, что биологическая эффективность штаммов $B S$ в отношении развития болезней картофеля при хранении сопоставима с эффективностью химического фунгицида. В то же время количество здоровых клубней в контроле не превышало 13,3 \%, в опытных вариантах после обработки клубней штаммами $B s-30,4-35,5$ \%, что увеличило выход здоровой продукции более чем в 2 раза.

Следует отметить, что при генотипировании фитопатогенных бактерий, микроорганизмов-антагонистов и биодеструкторов предложенным нами методом ДРИМ используются пары эндонуклеаз рестрикции, которым для осуществления реакции требуется 1-2 ч. В последние годы появились коммерческие препараты аналогичных ферментов с более коротким временем инкубации (до 5 мин, так называемый fast digest), например, эндонуклеазы рестрикции фирмы «Thermo Fischer Scientific, Inc.» (США). Они дают более быстрый результат, но это сопряжено с определенным риском неполного расщепления геномной ДНК, что искажает вид генетического профиля.

В литературе обсуждаются различные способы генотипирования псевдомонад. В частности, при генотипировании 232 изолятов с помощью метода пульс-гель электрофореза (pulsed-field gel electrophoresis, PFGE) и мультилокусного анализа тандемных повторов (multiple locus variable-number tandem repeat analysis, MLVA), совпадение результатов составило всего $91 \%$ (36). Эти данные еще раз подчеркивают необходимость применения методов, обладающих высокой разрешающей способностью и позволяющих детектировать большое число фрагментов ДНК в анализируемых геномах. Генотипирование видов рода Pectobacterium часто проводится с использованием мультилокусного секвенирования различного числа генов «домашнего хозяйства» - от четырех (37) до тринадцати (38).

Итак, разработанный нами метод генетической паспортизации (метод ДРИМ - двойное расщепление и избирательное мечение) помогает выявлять и однозначно идентифицировать штаммы фитопатогенных бактерий родов Pectobacterium и Pseudomonas и их антагонистов в процессе фитосанитарного мониторинга при развитии эпифитотий бактериозов, что, в частности, необходимо для разработки научно обоснованных фитосанитарных технологий выращивания и хранения картофеля. Также метод ДРИМ генетически идентифицирует штаммы бактерий-деструкторов из рода Pseudomonas, что позволяет контролировать идентичность отобранных штаммов в процессе их коммерческого использования (паспортизация). При генотипировании методом ДРИМ удается визуализировать большое число фрагментов ДНК (в этой работе - более 40), распределение которых характеризует и индивидуализирует бактериальный штамм. Для каждого вида микроорганизма необходим предварительный подбор ферментов рестрикции, дающий оптимальное число и размер фрагментов ДНК на фильтре. Сочетание метода ДРИМ и определения биологической активности показало, что из изученных штаммов Bacillus subtilis (Bs) наиболее выраженными антагонистическими свойствами по отношению к возбудителям кольцевой гнили, фитофтороза и фузариоза обладал штамм Bs И-5-12/23. Послеуборочная обработка картофеля его водной суспензией также выявила высокую биологическую эффективность, проявившуюся в существенном снижении пораженности клубней при хранении по сравнению с результатами, полученными при применении химического препарата Максим, КС. Метод ДРИМ может использоваться при изучении популяций микроорганизмов в 


\section{Л ИТ Е РАТ У РА}

1. Czajkowski R., Pérombelon M.C.M., Jafra S., E. Lojkowska E., M. Potrykus M., van der Wolf J.M., Sledz W. Detection, identification and differentiation of Pectobacterium and Dickeya species causing potato blackleg and tuber soft rot: a review. Annals of Applied Biology, 2015, 166(1): 18-38 (doi: 10.1111/aab.12166).

2. Лазарев А.М. Ареал и зоны распространенности черной ножки картофеля Erwinia carotovora subsp. atroseptica (van Hall) Dye. Вестник защиты растений, 2012, 3: 70-72.

3. Xiu J.-H., Ji G.-H., Wang M., Yang Y.-L., Li C.-Y. Molecular identification and genetic diversity in Konnyaku's soft rot bacteria. Acta Microbiologica Sinica, 2006, 46(4): 522-525.

4. Nabhan S., Wydra K., Linde M., Debener T. The use of two complementary DNA assays, AFLP and MLSA, for epidemic and phylogenetic studies of pectolytic enterobacterial strains with focus on the heterogeneous species Pectobacterium carotovorum. Plant Pathology, 2012, 61(3): 498-508 (doi: 10.1111/j.1365-3059.2011.02546.x).

5. Pritchard L., Humphris S., Saddler G.S., Parkinson N.M., Bertrand V., Elphinstone J.G., Toth I.K. Detection of phytopathogens of the genus Dickeya using a PCR primer prediction pipeline for draft bacterial genome sequences. Plant Pathology, 2013, 62(3): 587-596 (doi: 10.1111/j.1365-3059.2012.02678.x).

6. Терлецкий В.П., Тыщенко В.И., Новикова И.И., Бойкова И.В., Тюлебаев С.Д., Шахтамиров И.Я. Эффективный метод генетической паспортизации штаммов Bacillus subtilis перспективных продуцентов биопрепаратов. Микробиология, 2016, 85(1): 50-55 (doi: 10.7868/S0026365616010134).

7. Terletskiy V., Kuhn G., Francioli P., Blanc D. Application and evaluation of double digest selective label (DDSL) typing technique for Pseudomonas aeruginosa hospital isolates. Journal of Microbiological Methods, 2008, 72: 283-287 (doi: 10.1016/j.mimet.2007.12.006).

8. Terletski V., Schwarz S., Carnwath J., Niemann H. Typing of Salmonella enterica subsp. enterica serovars Choleraesuis, Typhimurium, Dublin and laboratory strains of Escherichia coli using subtracted restriction fingerprinting (SRF). Microbiological Research, 2003, 158(2): 135-142 (doi: 10.1078/0944-5013-00191).

9. des Essarts Y.R. Cigna J., Quêtu-Laurent A., Caron A., Munier E., Beury-Cirou A., Helias V., Faurea D. Biocontrol of the potato blackleg and soft rot diseases caused by Dickeya dianthicola. Applied and Environment Microbiology, 2016, 82(1): 268-278 (doi: 10.1128/AEM.02525-15).

10. Czajkowski R., Pérombelon M.C.M., van Veen J.A., van der Wolf J.M. Control of blackleg and tuber soft rot of potato caused by Pectobacterium and Dickeya species: a review. Plant Pathology, 2011, 60(6): 999-1013 (doi: 10.1111/j.1365-3059.2011.02470.x).

11. Rahman M.M., Ali M.E., Khan A.A., Akanda A.M., Uddin M.K., Hashim U., Abd Hamid S.B. Isolation, characterization, and identification of biological control agent for potato soft rot in Bangladesh. The Scientific World Journal, 2012, 2012: 723293 (doi: 10.1100/2012/723293).

12. Terletskii V.P., Lazarev A.M. On genotyping bacterial strains of the genera Pectobacterium and Pseudomonas: pathogens of bacterioses in potatoes. Cytology and Genetics, 2019, 53(3): 212-218 (doi: 10.3103/S0095452719030058).

13. Luo S., Xu T., Chen L., Chen J., Rao C., Xiao X., Wan Y., Zeng G., Long F., Liu C., Liu Y. Endophyte-assisted promotion of biomass production and metal-uptake of energy crop sweet sorghum by plant-growth-promoting endophyte Bacillus sp. SLS18. Applied Microbiology and Biotechnology, 2012, 93: 1745-1753 (doi: 10.1007/s00253-011-3483-0).

14. Fürnkranz M., Lukesch B., Müller H., Huss H., Grube M., Berg G. Microbial diversity inside pumpkins: microhabitat-specific communities display a high antagonistic potential against phytopathogens. Microbial Ecology, 2012, 63(2): 418-428 (doi: 10.1007/s00248-011-9942-4).

15. Makhlouf A.H., Abdeen R. Investigation on the effect of chemical and biological control of bacterial soft root disease of potato in storage. Journal of Biology, Agriculture and Healthcare, 2014, 4(10): 31-44.

16. Ongena M., Henry G., Thonart P. The role of cyclic lipopeptides in the biocontrol activity of Bacillus subtilis. In: Recent Developments in Management of Plant Diseases. Plant Pathology in the 21 st Century (Contributions to the 9th International Congress), vol. 1 /U. Gisi, L. Chet, M.L. Guillino (eds.). Springer, Dordrecht, 2010: 59-69 (doi 10.1007/978-1-4020-8804-9-5).

17. Patel H., Tscheka C., Edwards K., Karlsson G., Heerkotz H. All-or-none membrane permeabilization by fengycin-type lipopeptides from Bacillus subtilis QST713. Biochimica et Biophysica Acta, 2011, 1808(8): 2000-2008 (doi: 10.1016/j.bbamem.2011.04.008).

18. Cawoy H., Mariutto M., Henry G., Fisher C., Vasilyeva N., Thonart P., Dommes J., Ongena M. Plant defense stimulation by natural isolates of Bacillus depends on efficient surfactin production. Molecular Plant-Microbe Interactions, 2014, 27(2): 87-100 (doi: 10.1094/MPMI-09-13-0262-R). 
19. Falardeau J., Wise C., Novitsky L., Avis T.J. Ecological and mechanistic insights into the direct and indirect antimicrobial properties of Bacillus subtilis lipopeptides on plant pathogens. Journal of Chemical Ecology, 2013, 39: 869-878 (doi: 10.1007/s10886-013-0319-7).

20. Pieterse C.M.J., Zamioudis C., Berendsen R.L., Weller D.M., van Wees S.C.M., Bakker P.A.H.M. Induced systemic resistance by beneficial microbes. Annual Review of Phytopathology, 2014, 52: 347-375 (doi: 10.1146/annurev-phyto-082712-102340).

21. Максимов И.В., Абизгильдина Р.Р., Пусенкова Л.И. Стимулирующие рост растений микроорганизмы как альтернатива химическим средствам защиты от патогенов (обзор). Прикладная биохимия и микробиология, 2011, 47(4): 373-385.

22. Manidipa R., Dutta S., Venkata R. Pseudomonads: potential biocontrol agents of rice diseases. Research Journal of Agriculture and Forestry Sciences, 2013, 1(9): 19-25.

23. Новикова И.И., Бойкова И.В., Павлюшин В.А., Зейрук В.Н., Васильева С.В., Азизбекян Р.Р., Кузнецова Н.И. Перспективы использования биопрепаратов на основе микробов-антагонистов для защиты картофеля от болезней при хранении. Вестник защиты растений, 2013, 4: 12-21.

24. Новикова И.И., Литвиненко А.И. Биологическая эффективность биопрепаратов на основе микробов-антагонистов, применяемых против корневых гнилей огурца и вилта земляники, и их влияние на видовой состав микромицетов почвы. Вестник защиты растений, 2011, 2: 5-12.

25. Crépin A., Beury-Cirou A., Barbey C., Farmer C., Hélias V., Burini J.-F., Faure D., Latour X. NAcyl homoserine lactones in diverse Pectobacterium and Dickeya plant pathogens: diversity, abundance, and involvement in virulence. Sensors, 2012, 12(3): 3484-3497 (doi: 10.3390/s120303484).

26. Faure D., Dessaux Y. Quorum sensing as a target for developing control strategies for the plant pathogen Pectobacterium. European Journal of Plant Pathology, 2007, 119: 353-365 (doi: 10.1007/s10658-007-9149-1).

27. Ревина Т.А., Парфёнов И.А., Гвоздева Е.Л., Герасимова Н.Г., Валуева Т.А. Ингибитор химотрипсина и трипсина из клубней картофеля. Прикладная биохимия и микробиология, 2011, 47(3): 373-385.

28. Чеботарь В.К., Макарова Н.М., Шапошников А.И., Кравченко Л.В. Антифунгальные и фитостимулирующие свойства ризосферного штамма Bacillus subtilis Ч-13 - продуцента биопрепаратов. Прикладная биохимия и микробиология, 2009, 45(4): 465-471.

29. Compant S., Brader G., Muzammil S., Sessitsch A., Lebrihi A., Mathieu F. Use of beneficial bacteria and their secondary metabolites to control grapevine pathogen diseases. Bio Control, 2013, 58: 435-455 (doi: 10.1007/s10526-012-9479-6).

30. Франк Р.И., Кищенко В.И. Биопрепараты в современном земледелии. Защита и карантин растений, 2008, 4: 89-90.

31. Чулкина В.А., Торопова Е.Ю., Павлова О.И, Воробьева И.Г., Ховалыг Н.А. Современные экологические основы интегрированной защиты растений. Защита и карантин растений, 2008, 9: 18-21.

32. Novikova I.I., Shenin Y.D. Isolation, identification and antifungal activity of a gamair complex formed by Bacillus subtilis M-22, a producer of a biopreparation for plant protection from mycoses and bacterioses. Applied Biochemistry and Microbiology, 2011, 47: 817-826 (doi: 10.1134/S0003683811090031).

33. Новикова И.И., Бойкова И.В., Павлюшин В.А., Зейрук В.Н., Васильева С.В., Деревягина М.К. Биологическая эффективность препаративных форм на основе микробов-антагонистов для защиты картофеля от болезней при вегетации и хранении. Вестник защиты растений, 2015, 4(86): 12-19.

34. Laboratory guide for identification of plant pathogenic bacteria, third edition / N.W. Schaad, J.B. Jones, W. Chun. American Phytopathological Society Press, St Paul, USA, 2001.

35. Методические указания по регистрационным испытаниям фунгицидов в сельском хозяйстве. СПб, 2009.

36. Johansson E., Welinder-Olsson C., Gilljam M., Pourcel C., Lindblad A. Genotyping of Pseudomonas aeruginosa reveals high diversity, stability over time and good outcome of eradication. Journal of Cystic Fibrosis, 2015, 14(3): 353-360 (doi: 10.1016/j.jcf.2014.09.016).

37. Marković S., Stanković S., Jelušić A., Iličić R., Kosovac A., Poštić D., Popović T. Occurrence and identification of Pectobacterium carotovorum subsp. brasiliensis and Dickeya dianthicola causing blackleg in some potato fields in Serbia. Plant Disease, 2021, 105(4): 1080-1090 (doi: 10.1094/PDIS-05-20-1076-RE).

38. Sarfraz S., Sahi S.T., Oulghazi S., Riaz K., Rajput N.A., Atiq M., Tufail M.R., Hameed A., Faure D. Species diversity of Dickeya and Pectobacterium causing potato blackleg disease in Pakistan. Plant Disease, 2020, 104(5): $1492-1499$ (doi: 10.1094/PDIS-08-19-1743-RE).

${ }_{1}^{1}$ ФБНУ Всероссийский НИИ защиты растений, 196608 Россия, г. Санкт-Петербург-Пушкин, ш. Подбельского, 3,
Поступила в редакцию 9 июля 2021 года 
e-mail: valeriter@mail.ru $₫$, allazar54@mail.ru, irina_novikova@inbox.ru, irina_boikova@mail.ru;

2ГАОУ ВО ЛО Ленинградский государственный

университет им. А.С. Пушкина,

196605 Россия, г. Санкт-Петербург-Пушкин, ш. Петербургское, 10,

e-mail: valeriter@mail.ru;

${ }_{3}^{3}$ ФБНУ Всероссийский НИИ картофельного

хозяйства им. А.Г. Лорха,

140051 Россия, Московская обл., Люберецкий р-н, п. Красково,

ул. Лорха, 23, литера «В»,

e-mail: vzeyruk@mail.ru

Sel'skokhozyaistvennaya biologiya [Agricultural Biology], 2021, V. 56, № 5, pp. 910-923

\title{
ON DDSL-BASED GENOTYPING OF POTATO BACTERIOSIS AGENTS, THEIR ANTAGONISTS AND MICROBIAL BIODESTRUCTORS FOR PLANT PROTECTION AND ECOTECHNOLOGIES
}

\author{
V.P. Terletskiy1, $2 \bowtie$, A.M. Lazarev' ${ }^{1}$ I.I. Novikoval, I.V. Bojkova1, V.N. Zeyruk ${ }^{3}$
}

${ }^{1}$ All-Russian Research Institute of Plant Protection, 3, sh. Podbel'skogo, St. Petersburg, 196608 Russia, e-mail valeriter@mail.ru( $\square$ corresponding author), allazar54@mail.ru, irina_novikova@inbox.ru, irina_boikova@mail.ru; ${ }_{2}^{2}$ Pushkin Leningrad State University, 10, Petersburg Sh., St. Petersburg-Pushkin, 196605, e-mail valeriter@mail.ru;

${ }^{3}$ Lorkh All-Russian Research Institute of Potato Farming, 23, ul. Lorkha, pos. Korenevo, Lyubertsy Region, Moscow Province, 140051 Russia, e-mail vzeyruk@mail.ru;

ORCID:

Terletskiy V.P. orcid.org/0000-0003-4043-3823

Lazarev A.M. orcid.org/0000-0002-4282-0141

Novikova I.I. orcid.org/0000-0003-2816-2151

Bojkova I.V. orcid.org/0000-0001-6268-7301

Zeyruk V.N. orcid.org/0000-0002-2818-2141

The authors declare no conflict of interests

Acknowledgements:

The work was carried out in accordance with the State task, Section 5 "Plant protection and biotechnology" of the Federal Research Program of the State Academies of Sciences for 2013-2020, topic 15 "Molecular and nanotechnological bases for the development of biological and chemical new generation plant protection products for effective and safe use in integrated protection systems"

Received July 9, 2021

doi: 10.15389/agrobiology.2021.5.910eng

\section{Abstract}

Intensification of agricultural and industrial production necessitates environmentally friendly technologies to prevent human habitat from chemical pollutions. Microbial producers of biologicals for biocontrol of plant pathogens and hydrocarbon destructors for bioremediation are characterized by high spontaneous genetic variability which can lead to a change in their activity. Therefore, in stabilizing selection, it is necessary to confirm strain affiliation. Here, we presents data on the application of the double digest and selective label (DDSL) technique developed by us to study the genetic profiles of plant pathogenic agents of the genera Pseudomonas, Pectobacterium, their antagonists Bacillus subtilis (Bs), and the hydrocarbon destructors of the genus Pseudomonas. The study confirmed high biological efficiency of two selected $B s$ strains, the M-22 and I5-12/23 against bacterial diseases of stored potato tubers. In addition, destructors from the genus Pseudomonas were genetically identified. The aim of the study was to evaluate genetic diversity among Pseudomonas, Pectobacterium, and Bs strains to select effective microbial antagonists and hydrocarbon destructors. The DDSL technique uses two restriction endonucleases for bacterial genomic DNA digestion. Taq DNA polymerase supplemented into reaction mix provides simultaneous labeling DNA fragments by biotinylated deoxycytidine triphosphate (Bio-dCTP). Only fragments digested with one of the restriction enzymes producing fragments with 3 '-recessed ends are subjected to labeling. The second restriction enzyme produces only blunt ends which can not bind Bio-dCTP tag. As a result of DDSL reaction 20 to 50 clear DNA fragments are visualized on the filter, and their quantity and distribution are characteristic for each bacterial strain. Genotyping allows generating genetic profile for each bacterial strain, i.e., assigning a "bar-code" to the bacteria that identifies a given microbe with confidence. Genotyping P. atrosepticum D822 и G784 allows for identification of about 50 DNA fragments more than $20 \%$ of which were specific for only one of the compared strains. We used two pairs of restriction enzymes - XbaI/DraI and XbaI/Eco24I. Our results indicate on equal discriminatory ability of these two enzyme combinations when compared $P$. atrosepticum strains D822 и G784. We noted some advantage of XbaI/DraI enzymes because of its ability to identify differences in genetic profiles in a range of longer DNA fragments. The optimal enzymes for Pseudomonas genus genotyping were restriction endonucleases BcuI/Eco32I, for $B s$ the first restriction enzyme was SgsI (39 cleavage sites), the second was Eco32I reducing the size of the obtained DNA 
fragments. High antagonistic activity of B. subtilis strain I5-12/23 which belongs to I genotypic group was shown in laboratory experiments with artificial contamination of potato tubers with P. atrosepticum 1944 и $P$. carotovorum subsp. carotovorum 481. Index of development of bacterial soft rot disease after treatment of infected tubers by B. subtilis strain I5-12/23 was 0-0.02, in control the index was 4.04. Biological activity of this strain after treatment of infected tubers was up to $100 \%$ whereas chemical fungicide Maxim KS gave rise to only $77.7 \%$ value. Experiments conducted in potato storage houses confirmed high biological activity of two selected bacillus strains against bacterial diseases during potato tuber storage. B. subtilis strain I5-12/23 demonstrated highly expressed antagonistic activity against causal agents of bacterial soft rot, ring rot as well as fusarium dry rot potato diseases. Significant suppression of potato tuber diseases in comparison with control after treatment by selected antagonist strains was demonstrated, and this effect was comparable with that of chemical standard Maxim KS. Percentage of healthy tubers treated by bacillus strains was in the range of 30.4-35.5\% whereas in control this value did not exceed $13.3 \%$. Thus, yield of healthy products compared to control was 2.7 times higher. The most efficient $B$. subtilis strain I5-12/23 effectively suppressed causal agents for ring rot and fusarium dry rot potato diseases. Prevalence of ring rot disease was 2.6-2.9 \%, fusarium dry rot $-1.5-3.0 \%$, the values which are significantly lower than those in samples treated by B. subtilis M-22 and Maxim KS (4.8 and 3.5\%; 9.0 and 4.1\%, respectively). After genotyping, destructor strains of the genus Pseudomonas utilizing difficult-tooxidize compounds, including heavy oil fractions and polyaromatic hydrocarbons (benzopyrene, chrysene, phenanthrene, anthracene, chrysene, naphthalene) have been deposited in the VIZR collection. The range of their activity is enough to compose associations for utilizing specific pollutants. Thus, DREAM genotyping identifies bacterial strains to confirm their origin in the course of development and use of biological products for various purposes.

Keywords: restriction endonucleases, genotyping, plant pathogens, microbial antagonists, biodestructors, Pectobacterium, Pseudomonas, Bacillus subtilis, Solanum tuberosum L., potato. 